\title{
Recent advances in deep-sea coral science and emerging links to conservation and management of deep-sea ecosystems
}

\author{
Karen Miller $^{1, *}$, Helen Neil ${ }^{2}$, Di Tracey ${ }^{2}$ \\ ${ }^{1}$ Institute of Antarctic and Southern Ocean Studies, University of Tasmania, Private Bag 77, Hobart 7001, Australia \\ ${ }^{2}$ National Institute of Water \& Atmospheric Research (NIWA) Taihoro Nukurangi, 301 Evans Bay Parade, Greta Point, \\ Private Bag 14901, Kilbirnie, Wellington, New Zealand
}

\begin{abstract}
Conservation and management of deep-sea corals and coral reefs was the theme of the 4th International Deepsea Coral Symposium held in Wellington, New Zealand from 1 to 5 December 2008. A selection of resulting studies is published here. Recent advances in our understanding of deep-sea corals and associated ecosystems have demonstrated their high diversity, abundance, longevity and widespread global distribution. Such deep-water communities are increasingly threatened by anthropogenic environmental change (e.g. ocean acidity, fishing pressures) and require timely management policies and actions to reduce potential deleterious effects. The interdisciplinary nature of deep-sea coral research is a significant strength, helping to provide the broad base of knowledge and resources that are required for the conservation and management of this important ecological group.
\end{abstract}

KEY WORDS: Biodiversity $\cdot$ Ecology $\cdot$ Growth $\cdot$ Geochemical archives $\cdot$ Mapping tools $\cdot$ Conservation and management $\cdot$ Deep-sea corals $\cdot$ Symposium

Resale or republication not permitted without written consent of the publisher

The existence of deep-sea corals has been recognised since the time of Linnaeus, although only in recent decades have we developed the technology to fully explore the nature of deep-sea corals and coral reefs. Ironically, however, at a time when we are finally beginning to understand the incredible diversity and ecological importance of deep-sea coral ecosystems, we are also becoming aware of increasing threats to deep-sea corals, and the need for timely management to ensure their persistence.

Conservation and management of deep-sea corals and coral reefs was the theme of the 4th International Deepsea Coral Symposium held in Wellington, New Zealand, in December 2008. Continuing with the tradition of the previous 3 symposia (Willison et al. 2002, Freiwald \& Roberts 2005, George \& Cairns 2007) the meeting brought together almost 200 researchers, resource managers and policy makers from 23 countries, facilitating a global exchange of scientific knowledge of deep-sea corals and associated fauna.
The Symposium was hosted by New Zealand and Australia, responsible for 2 of the largest exclusive economic zones in the world, both of which contain abundant and diverse deep-sea coral fauna (e.g. Gordon 2009), and hence there was a strong focus on management measures and options to conserve and protect deep-sea corals and habitat. The studies that comprise this Theme Section represent a selection from the symposium, and synthesise recent advances in our understanding and conservation of deep-sea corals.

\section{Biodiversity}

Most marine scientists are aware of the incredible diversity of shallow-water corals; however, few realise that deep-sea corals (defined as those occurring at depths $>200 \mathrm{~m}$ and typically represented by species of Antipatharia, Scleractinia, Octocorallia and Stylasteri- 
dae) are as speciose ( $>3000$ species described representing $>65 \%$ of all corals; Cairns 2007), abundant, and widespread as their shallow-water counterparts. Despite the sustained efforts of leaders in the field of coral systematics - such as Frederick M. Bayer (Cairns 2009, this volume) - to document deep-sea corals, new species continue to be discovered. For example, 6 new species of stylasterids were discovered in a recent survey to seamounts on the Chatham Rise in New Zealand (Clark \& Rowden 2009) and, of 95 octocoral species recorded on the Tasmanian Seamounts in 2007, close to $15 \%$ of these are new to science (Williams et al. 2008). Increasingly, molecular technologies are allowing us to better document diversity and understand evolutionary processes in the deep sea (e.g. Dueñas \& Sánchez 2009, this volume); however, there remains much to learn. For example, isolation resulting in divergence and allopatric speciation has long been considered to be an important process affecting the diversity and distribution of seamount coral species. However, genetic data are beginning to show that many haplotypes and species are widespread and that the accepted paradigm of high seamount endemism many well be an artefact of limited sampling (Thoma et al. 2009, this volume).

\section{Interdisciplinary research}

One of the hallmarks of deep-sea coral research is its interdisciplinary nature; indeed papers presented at the Symposium covered themes as broad as systematics, ecology, paleoclimate and conservation. Notably, research on deep-sea corals involves collaboration across scientific disciplines; taxonomic resources are combined with studies of growth and ecophysiology, predictive modelling and mapping tools are used alongside diversity and distribution studies, proxies for deep-ocean conditions are being developed to elucidate climate change and ocean acidification, and all these resources are subsequently applied to conservation and management. One area where multidisciplinary research is particularly apparent is in the emerging links between environmental parameters and the distribution and biology of deep-sea corals. The work of Arantes et al. (2009), Carlier et al. (2009), Dodds et al. (2009), Hansson et al. (2009), Nonaka \& Muzik (2009), Roberts et al. (2009), Thresher (2009) (all this volume) utilise cross-disciplinary approaches to link factors such as substrate or oceanography with food supply, growth, or ecophysiology to provide an improved understanding of deep-sea coral diversity, distributions, and the role and functioning of ecosystems (Bo et al. 2009, Mosher \& Watling 2009, both this volume).

\section{Growth rates}

Growth is a key area of interest in deep-sea coral research, particularly how climate change and ocean acidification may affect skeletal architecture via dissolution and/or re-precipitation, and the consequences of this for the persistence of deep-sea coral species. Technological advances are facilitating in situ growth experiments such as have been undertaken in shallow water species for decades, and new studies confirm slow growth rates, high longevity, and low natural mortality for deep-sea corals, e.g. the recently reported longevity of Hawaiian proteinaceous corals in the order of several thousand years (Roark et al. 2009). Parrish et al. (2009, this volume) monitored colonies of the Hawaiian gold coral (Gerardia sp.) for $9 \mathrm{yr}$ and reported gross linear growth rates of only millimetres per year, suggesting colonies are very long-lived ( 950 yr). Radiometric validation methods provide veracity to in situ growth rates; radiocarbon and lead-210 ${ }^{210} \mathrm{~Pb}$ ) validation studies (Andrews et al. 2009, this volume) compare favourably with slow growth (up to $1.4 \mathrm{~cm} \mathrm{yr}^{-1}$ ) and high longevity (>145 yr) observed in previous studies of bamboo corals (Tracey et al. 2007). Thus the age and growth of complex branching forms of deep-sea corals appear akin to those of massive framework corals in shallow water that grow at rates of 5 to $40 \mathrm{~mm} \mathrm{yr}^{-1}$ (e.g. Fosså et al. 2002, Freiwald 2002, Adkins et al. 2004, Brooke \& Young 2009, this volume). Slow growth and longevity are 2 key life history parameters that contribute to the vulnerability of a species (e.g. Roberts \& Hawkins 1999) and this, along with fecundity and recruitment (e.g. Pires et al. 2009, this volume), are important considerations in the development of protection measures in the deep sea.

\section{Geochemical archives}

We are on the cusp of generating calibrated proxy records from deep-sea corals that have enormous potential to unravel regional and localised paleoenvironmental, paloeceanographic, and climatic variability causes and effects. Variation in stable isotope ratios and elemental composition are the result of changes in environmental parameters and/or animal behaviour, which can range from annual- to century-scale frequencies. Geochemical signatures within deep-sea coral skeletons can be influenced by changes in skeletal architecture during growth, and this needs to be considered when developing geochemical archives (Wisshak et al. 2009, this volume). Recent work has focused on isotopic and elemental ratios as proxies for potential climate signals-e.g. temperature, biogeo- 
chemical processes and nutrient supply - with variable success. Sherwood et al. (2009, this volume) have demonstrated the use of stable isotopes in tracking biogeochemical processes (nutrient availability and trophic dynamics) across centennial time scales from long-lived bamboo corals, and Risk et al. (2009, this volume) have applied these approaches to contemporary studies of nutrification. Deep-sea coral records are also providing unprecedented time-series information (potentially through the Holocene and older) for a sector of the ocean that has sparse historical records, often at best a small number of shipboard observations, hence deep-sea corals are well placed to provide baseline evaluation of the impacts of future environmental and climatic change.

\section{Mapping tools}

The conservation and sustainable management of the marine environment requires, amongst other things, objective and quantitative measures of seafloor habitats. Methods for submarine habitat and biodiversity mapping within the deep sea have advanced rapidly, and have been aided by high-resolution noninvasive tools such as remotely operated vehicles (ROVs), video and still camera systems, and acoustic techniques. Exploration has highlighted the physical complexity of the habitat, the combination of environmental and biological conditions that promote habitation by a given species, and the difficulty of acquiring comprehensive and unambiguous data at the seafloor over large areas. Concomitantly, there has been a rapid rise in studies that document the spatial distribution and areal extent of deep-sea coral reefs and their contribution to continental margin sedimentary systems (e.g. Orejas et al. 2009, this volume), while predictive modeling as a tool for describing large areas of seafloor that have the potential to support coral gardens (e.g. Woodby et al. 2009, this volume) are also being used where physical data are few.

Deep-sea corals are often associated with seamounts and other complex underwater terrains that abound in the deep sea. These important biodiversity hotspots are increasingly observed via non-destructive techniques, often resulting in large databases which need to be assimilated for them to be useable by conservation, fisheries and intergovernmental managers and policy makers (e.g. Costello 2009, this volume). Innovations such as machine-learning algorithms that estimate coral density from remotely collected video footage (Purser et al. 2009, this volume) are leading the way in the synthesis of vast deep-sea datasets, and will undoubtedly have widespread application across marine science.

\section{Threats and conservation}

Some of the most important end-users of the accumulating knowledge on deep-sea corals and coral reefs are environmental science managers and policy makers. Deep-sea corals face considerable threat from ocean acidification or shoaling of the aragonite saturation horizon (e.g. Guinotte et al. 2006), and future distribution of deep-sea coral communities and ecosystems will almost certainly be influenced by climate change (e.g. Fautin et al. 2009, this volume). Climate change is not, however, the only process threatening deep-sea corals. Bottom trawl fishing both damages corals (Heifetz et al. 2009, this volume) and reduces coral biomass (Althaus et al. 2009, Bruckner 2009, both this volume). At an international level, the United Nations General Assembly (UNGA) Resolution 61/105 called for States to protect vulnerable marine ecosystems (VMEs), including coldwater corals, from destructive fishing practices in international waters. A precautionary best practice approach for minimising impacts from high-seas fisheries on VMEs has resulted in some regional fisheries management organizations and governments acting on the UNGA resolution to prevent significant adverse impacts to VMEs (Brock et al. 2009, Penney et al. 2009, both this volume). Some deep-sea corals have protected species status as a result of the closure of seamounts to fishing, and the effect of fishing closures on deep-sea corals is being carefully monitored in some locations. Critically, however, recovery of deep-sea corals from the effects of fishing is likely to be slow. Coral communities on Tasmanian seamounts showed no signs of recovery even 10 yr after closure of the area to fishing (Althaus et al. 2009), indicating critical time lags between management actions and measurable effects on coral communities.

\section{Conclusions}

The Deepsea Coral Symposium provided an important forum where those who are actively involved in research and management of deep-sea corals and ecosystems could establish current knowledge at the same time as discussing future directions. Continuing discoveries, and an increased understanding of biodiversity and distributions of deep-sea corals and their immediate threats, will input directly to the designation and management of high-seas marine protected areas (Hall-Spencer et al. 2009, this volume) as well as the identification of VMEs and management actions associated with these (Hourigan 2009, Parker et al. 2009, both this volume).

The outcomes of the symposium will enhance the study of deep-sea corals and ecosystems through 
improved international data sharing and collaboration, combined taxonomic resources, and the development of remote sensing and mapping techniques to substantially improve knowledge of ecosystem distributions. The calibration of environmental proxies derived from deep-sea corals, the climate variability that these elucidate, and their application to environmental questions are critical for providing time-series in a poorly known area of the ocean, especially in relation to the effects of ocean acidification. Advancing molecular technologies are also allowing us to better document diversity and understand evolutionary processes in the deep sea, contributing to development of global databases and the improved conservation and management of deepsea corals. We look forward to a continuation of the trend of international cooperation, and to the establishment of a framework and strategy for deep-sea coral exploration, research, conservation and management.

Acknowledgements. We thank all the authors of the many manuscripts that were submitted for consideration to the Theme Section. Space was limited and many difficult decisions were made. We hope to see more papers generated from the symposium over future publications. The $>100$ reviewers that contributed thorough and thoughtful reviews are also thanked. The Symposium would not have been possible without the International Scientific Committee, the symposium host National Institute of Water and Atmospheric Research (NIWA), major sponsor the National Oceanic and Atmospheric Association (NOAA), as well as all the attendees. Other sponsors who ensured the success of the symposium were the Commonwealth Scientific and Industrial Research Organisation Wealth from Oceans Flagship, US Department of the Interior Minerals Management Service, NZ Ministry of Fisheries, NZ Department of Conservation, United Nations Environment Programme, United States Geological Survey, Neptune Minerals, NZ Deepwater Group, and the Royal Society of New Zealand. We wish all the best to Tjeerd C.E. van Weering, the Royal Netherlands Institute for Sea Research, and organisers of the 5th Deepsea Coral Symposium (to be held in the Netherlands, 2012), and look forward to continued interdisciplinary and collaborative discussions following on from those established by previous Symposia.

\section{LITERATURE CITED}

- Adkins JF, Henderson GM, Wang Sl, O'Shea S, Mokadem F (2004) Growth rates of the deep-sea scleractinia Desmophyllum cristagalli and Enallopsammia rostrata. Earth Planet Sci Lett 227:481-490

Althaus F, Williams A, Schlacher TA, Kloser RJ and others (2009) Impacts of bottom trawling on deep-coral ecosystems of seamounts are long-lasting. Mar Ecol Prog Ser 397:279-294

Andrews AH, Stone RP, Lundstrom CC, DeVogelaere AP (2009) Growth rate and age determination of bamboo corals from the northeastern Pacific Ocean using refined ${ }^{210} \mathrm{~Pb}$ dating. Mar Ecol Prog Ser 397:173-185

Arantes RCM, Castro1 CB, Pires DO, Seoane JCS (2009) Depth and water mass zonation and species associations of cold-water octocoral and stony coral communities in the southwestern Atlantic. Mar Ecol Prog Ser 397:71-79
Bo M, Bavestrello G, Canese S, Ginsti M, Salvati E, Angiolillo M, Greco S (2009) Characteristics of a black coral meadow in the twilight zone of the central Mediterranean Sea. Mar Ecol Prog Ser 397:53-61

Brock R, English E, Kenchington E, Tasker M (2009) The alphabet soup that protects cold-water corals in the North Atlantic. Mar Ecol Prog Ser 397:355-360

> Brooke S, Young CM (2009) In situ measurement of survival and growth of Lophelia pertusa in the northern Gulf of Mexico. Mar Ecol Prog Ser 397:153-161

> Bruckner AW (2009) Rate and extent of decline in Corallium (pink and red coral) populations: existing data meet the requirements for a CITES Appendix II listing? Mar Ecol Prog Ser 397:319-332

Cairns SD (2007) Deep-water corals: an overview with special reference to diversity and distribution of deep-water scleractinian corals. Bull Mar Sci 81:311-322

$>$ Cairns SD (2009) Influence of Frederick (Ted) M. Bayer on deep-water octocoral research. Mar Ecol Prog Ser 397: $7-10$

Carlier A, Le Guilloux AE, Olu K, Sarrazin J, Mastrototaro F, Taviani M, Clavier J (2009) Trophic relationships in a deep Mediterranean cold-water coral bank (Santa Maria di Leuca, Ionian Sea). Mar Ecol Prog Ser 397:125-137

Clark MR, Rowden AA (2009) Effect of deepwater trawling on the macro-invertebrate assemblages of seamounts on the Chatham Rise, New Zealand. Deep-Sea Res I 56: $1540-1554$

Costello MJ (2009) Distinguishing marine habitat classification concepts for ecological data management. Mar Ecol Prog Ser 397:253-268

> Dodds LA, Black KD, Orr H, Roberts JM (2009) Lipid biomarkers reveal geographical differences in food supply to the cold-water coral Lophelia pertusa (Scleractinia). Mar Ecol Prog Ser 397:113-124

> Dueñas LF, Sánchez JA (2009) Character lability in deep-sea bamboo corals (Octocorallia, Isididae, Keratoisidinae). Mar Ecol Prog Ser 397:11-23

Fautin DG, Guinotte JM, Orr JC (2009) Comparative depth distribution of corallimorpharians and scleractinians (Cnidaria: Anthozoa). Mar Ecol Prog Ser 397:63-70

Fosså JH, Mortensen PB, Furevik DM (2002) The deep-water coral Lophelia pertusa in Norwegian waters: distribution and fishery impacts. Hydrobiologia 471:1-12

Freiwald A (2002) Reef-forming cold-water corals. In: Wefer G, Billett D, Hebbeln D, Jørgensen BB, Schlüter M, Van Weering $\mathrm{T}$ (eds) Ocean margin systems. Springer, Berlin, p 365-385

Freiwald A, Roberts JM (2005) Cold-water corals and ecosystems. Erlangen Earth Conference Series. Springer, Berlin

George RY, Cairns SD (eds) (2007) Deep-sea coral ecosystems: biology and geology. Proc Third Int Symp on Deepsea corals. Bull Mar Sci 81:309-559

Gordon DP (2009) New Zealand inventory of biodiversity, I. Kingdom Animalia: Radiata, Lophotrochozoa, Deuterostomia. Canterbury University Press, Christchurch, NZ

> Guinotte JM, Orr J, Cairns S, Freiwald A, Morgan L, George R. (2006) Will human-induced changes in seawater chemistry alter the distribution of scleractinian bioherms? Front Ecol Environ 4:141-146

> Hall-Spencer JM, Tasker M, Soffker M, Christiansen S, Rogers S, Campbell M, Hoydal K (2009) Design of Marine Protected Areas on high seas and territorial waters of Rockall Bank. Mar Ecol Prog Ser 397:305-308

- Hansson L, Agis M, Maier C, Weinbauer MG (2009) Community composition of bacteria associated with cold-water coral Madrepora oculata: within and between colony vari- 
ability. Mar Ecol Prog Ser 397:89-102

Heifetz J, Stone RP, Shotwell SK (2009) Damage and disturbance to coral and sponge habitat of the Aleutian Archipelago. Mar Ecol Prog Ser 397:295-303

Hourigan TF (2009) Managing fishery impacts on deep-water coral ecosystems of the USA: emerging best practices. Mar Ecol Prog Ser 397:333-340

Mosher CV, Watling L (2009) Partners for life: a brittle star and its octocoral host. Mar Ecol Prog Ser 397:81-88

Nonaka M, Muzik K (2009) Recent harvest records of commercially valuable precious corals in the Ryuku Archipelago. Mar Ecol Prog Ser 397:269-277

Orejas C, Gori A, Lo Iacono C, Puig P, Gili JM, Dale MRT (2009) Cold-water corals in the Cap de Creus canyon, northwestern Mediterranean: spatial distribution, density and anthropogenic impact. Mar Ecol Prog Ser 397:37-51

Parker SJ, Penney AJ, Clark MR (2009) Detection criteria for managing trawl impacts on vulnerable marine ecosystems in high seas fisheries of the South Pacific Ocean. Mar Ecol Prog Ser 397:309-317

Parrish FA, Roark EB (2009) Growth validation of gold coral Gerardia sp. in the Hawaiian Archipelago. Mar Ecol Prog Ser 397:163-172

Penney AJ, Parker SJ, Brown JH (2009) Protection measures implemented by New Zealand for vulnerable marine ecosystems in the South Pacific Ocean. Mar Ecol Prog Ser 397:341-354

Pires DO, Castro CB, Silva JC (2009) Reproductive biology of the deep-sea pennatulacean Anthoptilum murrayi (Cnidaria, Octocorallia). Mar Ecol Prog Ser 397:103-112

Purser A, Bergmann M, Lundälv T, Ontrup J, Nattkemper TW (2009) Use of machine-learning algorithms for the automated detection of cold-water coral habitats: a pilot study. Mar Ecol Prog Ser 397:241-251

Risk MJ, Sherwood OA, Nairn R, Gibbons C (2009) Tracking the record of sewage discharge off Jeddah, Saudi Arabia, since 1950, using stable isotope records from antipatharians. Mar Ecol Prog Ser 397:219-226

Roark EB, Guilderson TP, Dunbar RB, Fallon SJ, Mucciaronea DA (2009) Extreme longevity in proteinaceous deep-sea corals. Proc Natl Acad Sci USA 106:5204-5208

> Roberts CM, Hawkins JP (1999) Extinction risk in the sea. Trends Ecol Evol 14:241-246

$>$ Roberts JM, Davies AJ, Henry LA, Dodds LA and others (2009) Mingulay reef complex: an interdisciplinary study of cold-water coral habitat, hydrography and biodiversity. Mar Ecol Prog Ser 397:139-151

Sherwood OA, Thresher RE, Fallon SJ, Davies DM, Trull TW (2009) Multi-century time-series of ${ }^{15} \mathrm{~N}$ and ${ }^{14} \mathrm{C}$ in bamboo corals from deep Tasmanian seamounts: evidence for stable oceanographic conditions. Mar Ecol Prog Ser 397: 209-218

> Thoma JN, Pante E, Brugler MR, France SC (2009) Deep-sea octocorals and antipatharians show no evidence of seamount-scale endemism in the NW Atlantic. Mar Ecol Prog Ser 397:25-35

Thresher RE (2009) Environmental and compositional correlates of growth rate in deep-water bamboo corals (Gorgonacea; Isididae). Mar Ecol Prog Ser 397:187-196

Tracey DM, Neil H, Marriott P, Andrews AH, Calliet GM, Sanchez JA (2007) Age and growth of 2 genera of deepsea bamboo corals (family Isididae) in New Zealand waters. Bull Mar Sci 81:393-408

Williams A, Althaus F, Bax N (eds) (2008) Research and monitoring for benthic ecosystems in Commonwealth Marine Protected Areas. Final Progress Report to the Australian Government Department of the Environment, Water, Heritage and the Arts, Hobart

Willison M, Hall J, Gass SE, Kenchington ELR, Butler M, Doherty P (eds) (2002) Proceedings of the First International Symposium on Deep-Sea Corals. Ecology Action Centre, Halifax, Nova Scotia

Wisshak M, López Correa M, Zibrowius H, Jakobsen J, Freiwald A (2009) Skeletal reorganisation affects geochemical signals, exemplified in the stylasterid hydrocoral Errina dabneyi (Azores Archipelago). Mar Ecol Prog Ser 397: 197-208

- Woodby D, Carlile D, Hulbert L (2009) Predictive modeling of coral distribution in the Central Aleutian Islands, USA. Mar Ecol Prog Ser 397:227-240 